\section{Jurnal Huknm Adigamâ}

Volume 2 Nomor 2, Desember 2019

E-ISSN : 2655-7347
Tanggung Jawab Hukum Pelaku Usaha Atas Peredaran Kosmetka Yang Diduga Mengandung Bahan Berbahaya Dan Tidak Memenuhi Standart Mutu Menurut Undang-Undang Nomor 8 Tahun 1999 tentang Perlindungan Kosumen (Studi Kasus Produk Kosmetika Hasil Rilis BPOM)

\title{
Tanggung Jawab Hukum Pelaku Usaha Atas Peredaran Kosmetika Yang Diduga Mengandung Bahan Berbahaya Dan Tidak Memenuhi Standart Mutu Menurut Undang-Undang Nomor 8 Tahun 1999 tentang Perlindungan Kosumen (Studi Kasus Produk Kosmetika Hasil Rilis BPOM)
}

\author{
Dede Afandi Hamid \\ (Mahasiswa Program S1 Fakultas Hukum Universitas Tarumanagara) \\ (Email : dedeh.fh@stu.untar.ac.id)
}

\section{DR. Ermanto Fahamsyah, S.H, M.H.}

(Corresponding Author)

(Dosen Fakultas Hukum Univesitas Jember, Meraih Sarjana Hukum dari Fakultas Hukum Universitas Jember (2002), Magister Hukum dari Fakultas Hukum Universitas Indonesia (2008), Doktor Ilmu Hukum dari Fakultas Hukum Universitas Indonesia (2013)

(Email : ermanto_fahamsyah@yahoo.co.id)

\begin{abstract}
UUPK has explained that the legal instrument which protect the consumers was not intended to shut off the business of businessmen. But actually it becomes a Healthy Business Season and becomes a strong company in facing up the rivalry through the supply of high quality goods and services.

Human was perfectly created by God. The willingness in every human to appear more attractive and perfect has become a trend, not only for women but also men as well as teenagers that we are called "millennials" becomes a proper things.

The definition of cosmetic under The Regulation of Ministry of Health 1175/2010 about the cosmetic production permit is the ingredients and preparations to be used on the outside of the human body (epidermis, hair, nails, mouth, and outer genital organs). Head of BPOM appeals to the public to be smart consumers in choosing cosmetics. During 2018, BPOM has foreclosed illegal cosmetics worth 106.9 billion rupiah. In that Case, BPOM asked to the public to avoid some cosmetic products.
\end{abstract}

Keywords : Consumers protection, responsibility, cosmetics

\section{PENDAHULUAN}

\section{A. Latar Belakang}

Kebutuhan kosmetika sekarang itu seperti menjadi kebutuhan primer bagi masyarakat yang menginginkan penampilan yang cantik. Keadaan demikian dimanfaatkan oleh para pelaku usaha. Konsumen berada diposisi lemah karena menjadi objek bisnis untuk meraih keuntungan yang besarnya 
Volume 2 Nomor 2, Desember 2019

\section{E-ISSN : 2655-7347}

melalui promosi itu dan penjualan yang merugikan konsumen ${ }^{1}$. Untuk bisa menjamin penyelenggaraan Perlindungan Konsumen maka dari itu pemerintah Indonesia menuangkan Perlindungan Konsumen di dalam suatu produk hukum ${ }^{2}$. Terbentuklah Undang-Undang Nomor 8 Tahun 1999 tentang Perlindungan Konsumen berdasarkan Pasal 1 angka 1 UndangUndang Perlindungan Konsumen.

Perlindungan Konsumen adalah upaya yang menjamin ada kepastian hukum untuk memberi perlindungan kepada konsumen dan masyarakat. Diantara informasi yang beredar tentang barang atau jasa yang diperlukan konsumen tampaknya yang paling berpengaruh pada zaman ini adalah informasi bersumber dari pelaku usaha. Paling banyak dalam bentuk iklan dan label Badan Pengawas Obat dan Makanan tidak mengurangi pengaruh dari berbagai macam informasi pengusaha-pengusaha lainnya ${ }^{3}$. Namun, banyak pelaku usaha yang mengabaikan pentingnya label Badan Pengawas Obat dan Makanan (BPOM).

Peraturan mengenai persyaratan teknis kosmetik sudah diatur pada Peraturan Kepala Badan Pengawas Obat dan Makanan Republik Indonesia Nomor 19 Tahun 2015. Kosmetik harus sudah memenuhi persyaratan keamanan dan kemanfaatan yang dibuktikannya hasil uji atau referensi empiris atau ilmiah lain yang relevan ${ }^{4}$. Produk kosmetik yang dipasarkan tidak boleh menyebabkan kerusakan pada kesehatan manusia apabila memiliki label karena apabila mengalami kerugian yang bertanggung jawab adalah pelaku usaha yg mengedarkan produk tersebut ${ }^{5}$.

1 Gunawan Widjaja dan Ahmad Yani, Hukum Tentang Perlindungan Konsumen, Gramedia, Jakarta: 2003, hlm. 12.

${ }^{2}$ Susanti Adi Nugroho, Proses Penyelesaian Sengketa Konsumen Ditinjau dari Hukum Acara Serta Kendala Implementasinya, Kencana, Jakarta: 2011, hlm. 2.

${ }^{3}$ Celina Tri Siwi Kristiyanti, Hukum Perlindungan Konsumen, Sinar Grafika, Jakarta: 2014, hlm. 71.

${ }^{4}$ Pasal 3 angka (1) Peraturan Kepala Badan Pengawas Obat dan Makanan Republik Indonesia Nomor 19 Tahun 2015 tentang Persyaratan Teknis Kosmetika.

5 Max Planck Institute, "Advertising Cosmetic Products", International Review of Intellectual Property and Competition Law, Thomson Reuter, No. 28 Januari 1999, hlm. 1. 
Volume 2 Nomor 2, Desember 2019

E-ISSN : 2655-7347

Penulis ingin lebih fokus terhadap penemuan produk kosmetika yang mengandung bahan berbahaya hasil rilis BPOM mulai 2009 hingga 2018. Kepala BPOM memberi informasi kepada masyarakat agar menjadi konsumen yg pintar dalam membeli kosmetik. Pada tahun 2018, BPOM RI sudah menyita kosmetika yang ilegal senilai 106.9 miliar rupiah. Pada kesempatan itu BPOM meminta masyarakat menghindari beberapa kosmetik. Dikarenakan kosmetik tersebut dicurigai mengandung bahan terlarang dan berbahaya. Produk kosmetik tersebut antara lain : NYX Pensil Alis, MAC Pensil, Revlon Pensil Alis, Cream Natural 99, SP Whitening and Anti Acne, Temulawak Two Way Cake, New Papaya Whitening Soap, Quine Pearl Cream, Citra Day Cream, Citra Night Cream, serta La Widya Collagen Plus Vit E Day and Night Cream, Temulawak. Produk tersebut beberapa yang disita BPOM RI dalam tiga bulan terakhir di daerah Jakarta dan Serang.

Penjual produk kosmetik yang menyebabkan kerugian pada konsumen seharusnya bertanggung jawab pada kosmetik yg dijualnya. Tanggung jawab tersebut telah diatur dalam UUPK Pasal 19, pelaku usaha bertanggung jawab memberikan ganti kerugian pada kerusakan, pencemaran, dan/atau kerugian konsumen yang disebabkan mengkonsumsi barang yang dihasilkan atau perjualbelikan. Tanggung jawab pelaku usaha bisa berupa penggantian barang dan/atau jasa, atau pengembalian uang atau setara nilainya, atau perawatan kesehatan dan/atau memberikan santunan yang sesuai dengan ketentuan perundang-undangan yang berlaku.

Tanggung jawab tersebut dikenal istilah product liability, yaitu adalah suatu tanggung jawab hukum dari orang atau badan yang menghasilkan produk (producer, manufacture) atau dari badan atau orang yang bergerak dalam proses untuk menghasilkan produk (processor, assembler) atau dari orang atau badan yang menjual atau mendistribusikan (seller, distributor) produk-produk tersebut ${ }^{6}$.

${ }^{6}$ Erman Rajagukguk, dkk, Hukum Perlindungan Konsumen, Mandar Maju, Bandung: 2000, hlm. 46. 
Disamping itu, pelaku usaha juga melanggar kewajibannya yang ada pada Pasal 7 mengenai kewajiban terhadap pelaku usaha yaitu telah Menjamin mutu barang dan/atau jasa yang diproduksi dan/atau diperjual belikan berdasarkan ketentuan standar mutu barang dan/atau jasa yang berlaku dan Memberi kompensasi, ganti kerugian dan/atau penggantian atas kerugian akibat penggunaan, pemakaian dan pemanfaatan barang dan/atau jasa yang diperdagangkan nya. Bukan cuma kewajibannya saja sebagai pelaku usaha yang tidak dilaksanakan namun pelaku usaha juga melanggar hak-hak konsumen yang diatur dalam UUPK Pasal 4 yaitu Hak atas kenyamanan, keamanan, dan keselamatan dalam memakai barang dan/atau jasa serta memperoleh kompensasi ganti rugi dan/atau penggantian apabila barang yang diterimanya tidak seharusnya.

Setiap tahunnya BPOM DKI Jakarta melakukan pemusnahan terhadap kosmetika yang tidak memiliki izin-izin dan dikategorikan berbahaya. Melihat banyaknya penjualan yang dilakukan oleh pelaku usaha krim pemutih wajah berbahaya yang masih menjamur di DKI Jakarta, maka penulis mengambil objek penelitian ini dengan menuangkannya dalam bbentuk skripsi dengan judul "Tanggung Jawab Hukum Pelaku Usaha Atas Peredaran Kosmetika Yang Diduga Menandung Bahan Berbahaya Dan Tidak Memenuhi Standart Mutu Menurut UU No 8 Tahun 1999 Tentang Perlindungan Konsumen (Studi Kasus Poduk Kosmetika Hasil Rilis BPOM)"

\section{B. Rumusan Masalah}

Bagaimana tanggung jawab hukum pelaku usaha atas peredaran kosmetik yang diduga mengandung bahan berbahaya dan tidak memenuhi standart mutu yang merugikan konsumen ? 
Volume 2 Nomor 2, Desember 2019

E-ISSN : 2655-7347

\section{Metode Penelitian}

\section{Tipe Penelitian}

Tipe penelitian yang akan digunakan oleh Penulis adalah tipe hukum normatif. Alasan Penulis memilih metode ini dalam rangka mencari kebenaran koherensi adalah mendapatkan sesuatu yang secara aksiologis merupakan nilai atau ketetapan/aturam sebagai referensi untuk ditelaah. ${ }^{7}$

\section{Jenis dan Bahan Hukum}

Pada penelitian ini, Penulis ingin menggunakan jenis data sekunder yaitu bahan-bahan yang di peroleh dari telaah kepustakaan dan literature, untuk memecahkan masalah hukum dan sekalian memberikan preskripsi tentang apa yang seyogyanya, diperlukan dari sumberr penelitian. ${ }^{8}$ Penelitian yang akan dilakukan berdasarkan bahan sekunder yang di mana data ini berasal dari bahan-bahan sebagai berikut:

a. Bahan hukum primer tersebut, terdiri dari perundang-undangan dan peraturan lain yang mengikat, antara lain:

1) UUD Negara Republik Indonesia 1945;

2) Undang-Undang Nomor 8 Tahun 1999 Tentang Perlindungan Konsumen;

3) Undang-Undang Nomor 7 Tahun 2014 tentang Perdagangan;

4) Undang-Undang Nomor 36 Tahun 2009 Tentang Kesehatan;

5) Undang-Undang Menteri Kesehatan Republik Indonesia Nomor 1175/MenKes/PER/VIII/2010 tentang Notifikasi Kosmetika;

6) Peraturan Kepala Badan Pengawas Obat dan Makanan Republik Indonesia Nomor Hk.03.1.23.08.11.07517 Tahun 2011 tentang Persyaratan Teknis Bahan Kosmetika.

b. Bahan hukum sekunder, adalah bahan yang memberikan penerangan mengenai bahan hukum primer, contohnya pendapat atau doktrin para ahli, artikel-artikel, seminar-seminar, dan hasil karya-karya ilmiah

\footnotetext{
${ }^{7}$ Ibid., hal. 33
}

${ }^{8}$ Ibid., hal. 181. 
Volume 2 Nomor 2, Desember 2019

E-ISSN : 2655-7347

lainnya yang berhubungan dengan masalah perlindungan konsumen serta artikel dari internet.

c. Bahan-bahan nonhukum yaitu bahan penunjang di luar bahan hukum primer dan sekunder seperti Kamus Umum Bahasa Indonesia dan ensiklopedia serta petunjuk tambahan berupa wawancara dengan narasumber (ahli hukum).

\section{Pendekatan}

Penelitian hukum normatiif mengenal beberapa pendekatanpendekatan yaitu antara lain: ${ }^{9}$

a) Pendekatan Undang-Undang (statute approach);

b) Pendekatan kasus (case approach);

c) Pendekatan historis (historical approach);

d) Pendekatan komparatif (comparative approach); dan

e) Pendekatan konseptual (conseptual approach).

Pendekatan ini akan digunakan dalam penelitian adalah pendekatan UU (statute approach) dan konseptual (conseptual approach). Pendekatan undang-undang ini pendekatan yang di lakukan dengan cara menelaah UU maupun regulasi ini yang berkaitan dengan kasus yang dibahas dan pendekatan secara konseptual merupakan pendekatan yang beranjak dari pandangan dari doktrin di dalam ilmu hukum. ${ }^{10}$

Metode pendekatan ini dipilih karena dalam penelitian ini, Penulis melakukan telaah terhadap semua peraturan perUU dan doktrin-doktrin yang terkait dengan tanggung jawab hukum pelaku usaha perederan kosmetika yang diduga mengandung bahan berbahaya dan tidak memenuhi standart mutu yang beredar luas di Indonesia. Spesifikasi penelitian yang digunakan adalah penelitian secara preskriptif yang pada bagian akhirnya berisi saran.

\section{Teknik Pengumpulan Bahan Hukum}

${ }^{10}$ Ibid., hal. 135. 
Volume 2 Nomor 2, Desember 2019

E-ISSN : 2655-7347

Tekniik pengumpulan bahan hukum yang Penulis gunakan didalam penelitian ini yaitu dengan tinjauan pustaka atau liibrary research. Pengumpulan bahan-bahan hukum dari bahan hukum yang sekunder berasal dari artikel-artikel di internet dan wawancara kepada narasumber.

\section{Teknik Pengolahan Bahan Hukum}

Teknik pengolahan bahan hukum yg akan di gunakan Penulis adalah pengolahan yang secara runtut dan sistematis sehingga memudahkan Penulis melakukan analisis. Pengelolaan bahan hukum dilakukan secara siistematis bertujuan untuk dapat gambaran umum dari hasil penelitian.

\section{Teknik Analisis Bahan Hukum}

Teknik analisis bahan hukum Penulis menggunakan dalam penelitian ini yaitu dengan menggunakan metode-metode analisis bahan hukum kualitatif yaitu penelitian yang menekankan pada bahan-bahan hukum yang di peroleh dari brbagai sumber, seperti buku, artikel-artikel, jurnal, serta peraturan perundang-undangan.

\section{PEMBAHASAN}

\section{A. Tanggung Jawab Hukum Pelaku Usaha Atas Peredaran Kosmetika}

\section{Yang Merugikan Konsumen}

Peraturan Kepala BPOM Nomor KH. 00.01.432.6081 tentang Kosmetik yang mengandung bahan berbahaya dan zat warna yang dilarang (Public Warning), dimana pada 11 Desember 2017 BPOM juga merilis daftar kosmetik yang mengandung bahan berbahaya. Terdapat 26 daftar merk kosmetik yang harus di hindari karena mengandung bahan berbahaya diantaranya: merkuri, dekametason, klindomoasin, hidrokinon, asam retinoat, bahan perw arna merah K3, dan bahan pewarna merah K10.

Selain mengeluarkan Public Warning, BPOM juga melakukan sidak langsung ke beberapa tempat penjualan kosmetik seperti pusat-pusat perbelanjaan, pasar tradisional, apotik, dan lain-lain, dan mendapatkan produk kosmetik yang tercantum dalam Public Warning BPOM tersebut masih dijual di pasaran secara bebas seolah-olah tidak mengetahui telah 
Volume 2 Nomor 2, Desember 2019

E-ISSN : 2655-7347

dikeluarkan Publlic Warning oleh BPOM. BPOM bekerjasama dengan

Dinas Kesehatan serta aparat kepolisian setempat dan kemudian melakukan penyintaan terhadap produk-produk koosmetik yang diduga mengandung bahan berbahaya lainnya dan tidak sesuai degan standar mutu.

Tanggung jawab terhadap produk (product liability) yaitu tanggung jawab atas kerugian yg diakibatkan oleh penggunaan produk atau berkaitan dengan barang konsumsi. Termasuk di dalam pengertian produk tersebut tidak hanya suatu produk yang sudah jadi utuh secara keseluruhan.

\section{Kronologi Kasus}

PT. Srirejeki Perdana Steel, berkedudukan di Kampung Gombong RT.02/05, Kelurahan Pasir Gombong, Kecamatan Cikarang Utara, Kabupaten Bekasi, dalam hal ini memberi kuasa kepada Indrayati Mulyadi, Karyawan Swasta, beralamat di Jalan Pondok Kelapa Timur, Blok E 12/1, RT. 10/RW. 11, Kelurahan Pondok Kelapa, Kecamatan Duren Sawit, Jakarta Timur, berdasarkan Surat Kuasa Khusus tanggal 20 Oktober 2014, sebagai Pemohon Kasasi dahulu Tergugat, melawan Para Pekerja PT. Srirejeki Perdana Steel yang diwakili oleh Ganto Alamsyah, SH., dan kawan-kawan, Para Pengurus Pusat Federasi Perjuangan Buruh Jabodetabek, beralamat di Jalan Fatahilah, Kampung Pengkolan, RT.002/RW.04, Nomor 24, Desa Kali Jaya, Kecamatan Cikarang Barat, Kabupaten Bekasi, berdasarkan surat kuasa khusus tanggal 26 November 2014, sebagai Para Termohon Kasasi dahulu Para Penggugat.

Pemohon Kasasi melakukan pemutusan hubungan kerja terhadap 4 (empat) orang Pengurus Serikat Pekerja PT. Srirejeki Perdana Steel atas dasar alasan bahwa 4 (empat) orang Pengurus Serikat Pekerja PT. Srirejeki Perdana Steel tersebut membujuk para pekerja dan melakukan sabotase dengan memerintahkan para pekerja untuk mematikan mesin-mesin produksi dan mangajak para pekerja lainnya untuk melakukan Aksi Mogok, yang mana hal tersebut melanggar Peraturan Perusahaan Pasal 40 huruf (e), 
Volume 2 Nomor 2, Desember 2019

E-ISSN : 2655-7347

(f) dan (dd), dan termasuk dalam katagori pelanggaran berat. ${ }^{11)}$ Para Termohon Kasasi mendalihkan bahwa aksi mogok tersebut dilakukan secara spontan, tetapi mogok secara spontan tidak dikenal dalam sistem hukum Indonesia, khususnya dalam bidang Ketenagakerjaan, sehingga apapun alasannya, apa yang dilakukan oleh Para Termohon Kasasi dikatagorikan mogok kerja tidak sah karena Aksi Mogok yang dilakukan oleh Para Termohon Kasasi tidak dilakukan secara prosedural. Terhadap Aksi Mogok yang dilakukan Para Termohon Kasasi telah dilakukan pemanggilan untuk kembali bekerja oleh Pemohon Kasasi yang disampaikan baik melalui pengeras suara, pengumuman yang dipasang di luar dinding depan perusahaan dan di tempat-tempat yang mudah dilihat oleh Para Termohon Kasasi dan juga melalui Surat Panggilan I dan Surat Panggilan II, namum surat panggilan tersebut tidak diindahkan oleh Para Termohon Kasasi dengan alasan tidak perlu dipanggil karena Para Termohon Kasasi ada di lokasi perusahaan namun tidak mau melakukan pekerjaan selama tuntutan yang mereka ajukan agar Pengurus Serikat Pekerja di perusahaan dipekerjakan kembali belum dikabulkan oleh pengusaha. Faktanya Para Termohon Kasasi tidak bersedia untuk kembali bekerja, maka dapat dikatakan Para Termohon Kasasi tidak melaksanakan kewajiban untuk kembali bekerja. Tergugat menindaklanjuti hal tersebut dengan menerbitkan Surat Pemutusan Hubungan Kerja kepada para Para Termohon Kasasi.

Penolakan memenuhi panggilan kerja yang telah diperintahkan Pemohon Kasasi kepada Para Termohon Kasasi secara patut dan tertulis, mengakibatkan kehilangan hak bagi Para Termohon Kasasi untuk mendapatkan hak-hak yang seharusnya diterima (upah dan segala tunjangan yang bersifat tetap), karena ketidaksediaan Para Termohon Kasasi memenuhi panggilan untuk bekerja kembali di perusahaan Pemohon Kasasi atas kehendak Para Termohon Kasasi sendiri. Maka atas dasar tersebut upah

11) Putusan Kasasi Nomor 58 K/Pdt.Sus-PHI/2015 tentang perselisihan antara Pekerja PT. Srirejeki Perdana Steel vs PT. Srirejeki Perdana Steel. 
Volume 2 Nomor 2, Desember 2019

E-ISSN : 2655-7347

semenjak tanggal 14 November 2013 sampai dengan proses perselisihan ini diputus oleh Pengadilan Hubungan Industrial pada Pengadilan Negeri Bandung tidak dibayarkan kepada para Para Termohon Kasasi. Selain itu, tidak beralasan hukum pula apabila Para Termohon Kasasi diberikan upah proses selama perselisihan ini dimajukan ke Pengadilan Hubungan Industrial pada Pengadilan Negeri Bandung. Maka cukup beralasan apabila hubungan kerja antara para Para Termohon Kasasi dengan Pemohon Kasasi diakhiri sejak tanggal 30 November 2013 dan kepada Para Termohon Kasasi diberikan uang penggantian hak.

1. Putusan Kasasi

a. Mengabulkan gugatan Penggugat untuk sebagian;

b. Menyatakan putus hubungan kerja antara Pemohon Kasasi dengan Termohon Kasasi sejak 22 November 2013;

c. Menghukum Pemohon Kasasi membayar Uang Ganti Kerugian sesuai ketentuan Pasal 26 B Huruf d Kep: 78/MEN/2001;

d. Menghukum Pemohon Kasasi membayar Uang Ganti Kerugian sebesar perhitungan Pasal 26 B Huruf d Kep: 78/MEN/2001 kepada Termohon Kasasi;

e. Menolak gugatan Pemohon Kasasi untuk selain dan selebihnya; dan

f. Menghukum Termohon Kasasi membayar biaya perkara pada tingkat kasasi sebesar Rp.500.000,- (lima ratus ribu Rupiah).

Perlindungan terhadap hak pekerja telah diatur oleh Undang-Undang Nomor 13 Tahun 2003 tentang Ketenagakerjaan khususnya tentang upah dalam Pasal 88 Undang-Undang Nomor 13 Tahun 2003 tentang Ketenagakerjaan mengatur bahwa setiap pekerja/buruh berhak memperoleh penghasilan yang memenuhi penghidupan yang layak bagi kemanusiaan. Untuk mewujudkan hal tersebut, Pemerintah menetapkan kebijakan pengupahan yang melindungi pekerja/buruh salah satunya adalah kebijakan upah minimum. Upah minimum diarahkan untuk pencapaian kebutuhan hidup layak. Pengusaha dilarang membayar upah pekerja yang besarnya 
Volume 2 Nomor 2, Desember 2019

E-ISSN : 2655-7347

dibawah kebijakan upah minimum. ${ }^{12)}$ Permasalahannya, beberapa pekerja PT. Srirejeki Perdana Steel menerima upah pada bulan November 2013 yang besarnya tidak seperti yang biasa mereka terima. Bahkan beberapa pekerja menerima upah yang besarnya di bawah Surat Keputusan Gubernur Jawa Barat Nomor 1405 Tahun 2012 tentang Upah Minimum Kabupaten/Kota di Jawa Barat Tahun 2013. Pada dasarnya, upah yang diterima oleh para pekerja PT. Srirejeki Perdana Steel telah sesuai dengan kebijakan upah minimum. Beberapa pekerja PT. Srirejeki Perdana Steel menerima upah sebesar kebijakan upah minimum dan yang lainnya menerima upah yang besarnya di atas upah minimum. Menurut Bapak Faisal Rizza, S.H., M.H., menjadi permasalahan ketika upah minimum dijadikan upah standar padahal filosofi dari upah minimum itu sendiri adalah sebagai jaring pengaman. ${ }^{13)}$ Pengurangan upah para pekerja PT. Srirejeki Perdana Steel pada bulan November 2013 yang dilakukan oleh PT. Srirejeki Perdana Steel menyebabkan besarnya upah beberapa pekerja PT. Srirejeki Perdana Steel di bawah kebijakan upah minimum. Menurut Dr. Reytman Aruan, S.H., M.H., tidak selamanya pekerja mendapat upah sesuai dengan upah minimum. Jika pekerja tidak bekerja dan pengusaha membayarkan upah di bawah upah minimum, maka hal tersebut bukanlah suatu pelanggaran yang dilakukan oleh pengusaha. Akan tetapi, jika pekerja yang bersangkutan bekerja sesuai dengan waktu dan tugasnya maka mereka seharusnya tetap menerima upah yang sesuai. ${ }^{14)}$ Para pekerja PT. Srirejeki Perdana Steel tetap datang ke lokasi bekerja dan bersedia untuk melakukan kewajiban mereka untuk bekerja. Para pekerja tidak bekerja bukan atas dasar kehendak mereka sendiri, tetapi mereka dilarang untuk bekerja oleh pihak perusahaan.

Hubungan antara pekerja dan pengusaha merupakan hubungan kerja. Hubungan kerja pada dasarnya adalah hubungan antara kedua belah pihak,

\footnotetext{
${ }^{12)}$ Indonesia (II), Op.Cit., Pasal 90 Ayat (1).

13) Peneliti (III), Op.Cit.

14) Peneliti (II), Op.Cit.
} 
Volume 2 Nomor 2, Desember 2019

E-ISSN : 2655-7347

yaitu pengusaha dan pekerja/buruh, dengan suatu perjanjian dimana pihak kesatu (pekerja/buruh) mengikatkan dirinya pada pihak lain (si pengusaha) untuk bekerja dengan mendapatkan upah; dan pengusaha menyatakan kesanggupannya untuk mempekerjakan pekerja/buruh dengan membayar upah. ${ }^{15)}$ Perlindungan yang diberikan oleh hukum, terkait pula dengan adanya hak dan kewajiban, dalam hal ini yang dimiliki oleh manusia sebagai subyek hukum dalam interaksinya dengan sesama manusia serta lingkungannya. Sebagai subyek hukum manusia memiliki hak dan kewajiban untuk melakukan suatu tindakan hukum. ${ }^{16)}$ Hubungan yang terjadi antara pekerja dan pengusaha menimbulkan hak dan kewajiban bagi masing-masing pihak terhadap satu sama lainnya. Upah merupakan kewajiban utama pengusaha kepada pekerja. Upah sebagai imbalan yang diberikan pengusaha kepada pekerja atas kinerja pekerja. Pekerja berhak atas upah yang wajib diberikan kepadanya dari pengusaha. Ketika para pekerja PT. Srirejeki Perdana Steel tetap datang ke lokasi bekerja dan bersedia melakukan kewajiban mereka untuk bekerja, pekerja PT. Srirejeki Perdana Steel berhak memperoleh hak mereka berupa upah sebagai bentuk imbalan dari pengusaha. Sudah seharusnya pengusaha membayarkan upah para pekerja sebagaimana kedua belah pihak sepakati karena pekerja telah melakukan kewajibannya yaitu untuk bekerja. Upah dianggap sebagai kontraprestasi dari penunaian pekerjaan dipandang dari sudut sosial ekonomis. ${ }^{17)}$ Seharusnya, para pekerja PT. Srirejeki Perdana Steel tetap memperoleh hak mereka yaitu upah yang sesuai dengan upah yang mereka terima pada bulan sebelumnya dan sesuai dengan keputusan terkait kebijakan upah minimum.

Perlindungan terhadap hak pekerja oleh Undang-Undang Nomor 13 Tahun 2003 tentang Ketenagakerjaan juga diatur dalam Pasal 93 UndangUndang Nomor 13 Tahun 2003 tentang Ketenagakerjaan. Pasal 93 Ayat (1)

\footnotetext{
15) Zaeni Asyhadie, Op.Cit., hal. 52.

16) CST Kansil, Op.Cit., hal. 102.

17) F.X. Djumialdji, Op.Cit., hal. 8.
} 
Volume 2 Nomor 2, Desember 2019

E-ISSN : 2655-7347

Undang-Undang Nomor 13 Tahun 2003 tentang Ketenagakerjaan mengatur upah tidak dibayar apabila pekerja/buruh tidak melakukan pekerjaan. Pengecualian atas Pasal 93 Ayat (1) Undang-Undang Nomor 13 Tahun 2003 tentang Ketenagakerjaan tersebut, yaitu Pasal 93 Ayat (2) Undang-Undang Nomor 13 Tahun 2003 tentang Ketenagakerjaan. Ketentuan sebagaimana dimaksud dalam Pasal 93 Ayat (1) tidak berlaku, dan pengusaha wajib membayar upah apabila pekerja/buruh bersedia melakukan pekerjaan yang telah dijanjikan tetapi pengusaha tidak mempekerjakannya, baik karena kesalahan sendiri maupun halangan yang seharusnya dapat dihindari pengusaha ${ }^{18)}$ Pada kasus ini, para pekerja PT. Srirejeki Perdana Steel telah bersedia melakukan pekerjaan, tetapi pengusaha tidak mempekerjakan mereka dengan alasan demo tidak sah yang para pekerja PT. Srirejeki Perdana Steel lakukan pada hari sebelumnya. Selama berhari-hari pekerja PT. Srirejeki Perdana Steel yang datang ke lokasi bekerja namun tidak diperbolehkan bekerja, pihak pengusaha menganggap hal tersebut sebagai mangkir mengacu pada Pasal 140 ayat (1) Undang-Undang No. 13 Tahun 2003 tentang Ketenagakerjaan. Akhirnya pihak pengusaha memotong upah pekerja dengan dalil pekerja tidak bekerja.

Pada prinsipnya, upah hanya diberikan kepada pekerja yang masuk kerja. Prinsip ini dikenal dengan prinsip "No Work No Pay". Permasalahannya, para pekerja PT. Srirejeki Perdana Steel tetap bersedia bekerja karena mereka kembali ke lokasi kerja pada keesokan hari dan seterusnya tetapi, pengusaha tidak memperbolehkan mereka untuk bekerja. Dr. Reytman Aruan, S.H., M.H. menyatakan terdapat indikasi bahwa pengusaha terlampau responsif karena langsung tidak mengizinkan para pekerja untuk bekerja pada keesokan harinya setelah melakukan demo tidak sah. ${ }^{19)}$ Demo tidak sah yang dilakukan para pekerja PT. Srirejeki Perdana Steel itu cukup diberikan surat peringatan dari pengusaha karena demo tidak

\footnotetext{
${ }^{18)}$ Indonesia (II), Op.Cit., Pasal 93 Ayat (2) Huruf F.
}

19) Peneliti (II), Op.Cit. 
Volume 2 Nomor 2, Desember 2019

E-ISSN : 2655-7347

sah tersebut dapat dikatakan pelanggaran ringan. Pada kasus ini, tidak dapat diterapkan asas No Work No Pay. Asas No Work No Pay didasarkan pada kehendak pekerja, yaitu bahwa pekerja tidak melakukan pekerjaan atas dasar kemauannya sendiri maka upah tidak dibayar. Namun pada kasus ini, para pekerja PT. Srirejeki Perdana Steel tetap memiliki kemauan untuk bekerja. Jika dikaitkan dengan asas No Work No Pay, Bapak Juanda Pangaribuan, S.H., M.H. berpendapat tidak logis jadinya karena asas ini berlaku pada keadaan di mana pekerja tidak masuk kerja dalam waktu yang lama dan dapat dikatagorikan mangkir. ${ }^{20)}$ Jika pekerja yang bersangkutan bekerja sesuai dengan waktu dan tugasnya maka mereka seharusnya tetap menerima upah yang sesuai.

Perlindungan hukum terhadap upah pekerja tidak hanya diberikan oleh peraturan perundang-undangan, tetapi perlindungan hukum terhadap hak pekerja juga diberikan oleh hakim melalui putusannya. Perlindungan hukum adalah memberikan pengayoman kepada hak asasi manusia yang dirugikan orang lain dan perlindungan tersebut diberikan kepada masyarakat agar mereka dapat menikmati semua hak-hak yang diberikan oleh hukum atau dengan kata lain perlindungan hukum adalah berbagai upaya hukum yang harus diberikan oleh aparat penegak hukum untuk memberikan rasa aman, baik secara pikiran maupun fisik dari gangguan dan berbagai ancaman dari pihak manapun. ${ }^{21)}$

Pada pertimbangan hakim, perlindungan hukum didasari oleh peraturan perundang-undangan. Peraturan perundang-undangan telah memberikan perlindungan terhadap upah pekerja tetapi permasalahnnya, hakim memutus bertentangan dengan peraturan perundang-undangan. Dikaitkan dengan putusan PHI yang memutus untuk mempekerjakan para pekerja kembali tetapi tidak mengabulkan gugatan kekurangan upah, hal tersebut menjadi tidak sejalan. Dengan diputusnya para pekerja untuk bekerja kembali, maka pekerja dinyatakan tidak bersalah atas mogok kerja untuk melakukan demo.

\footnotetext{
20) Peneliti (I), Op.Cit.

21) Satjipto Rahardjo, Op.Cit., hal. 74.
} 
Volume 2 Nomor 2, Desember 2019

E-ISSN : 2655-7347

Para pekerja tidak dapat dinyatakan mangkir dan tidak kehilangan hak upah pekerja karena hak-hak pekerja pulih. Selain itu, sudah sepantasnya pekerja diberikan upah proses selama proses penyelesaian perselisihan. Bapak Juanda Pangaribuan, S.H., M.H. menyatakan, amar putusan PHI yang tidak mengabulkan gugatan kekurangan upah pekerja tentunya keliru karena PHI telah secara tidak langsung menyatakan bahwa pekerja tidak bersalah, oleh sebab itu hak-hak para pekerja ini sudah seharusnya dibayarkan. ${ }^{22)}$

\section{B. Hasil Wanwancara}

1. Riski Kurniawan S.H M.H, Kepala Sub Bagian Advokasi Hukum III ${ }^{23}$

Pada wawancara ini, penulis mengajukan pertanyaan kepada bapak Riski Kurniawan, S.H, M.H, selaku Kepala Sub Bagian Advokasi Hukum III, penulis ingin menanyakan apakah BPOM memiliki peraturan khusus atau SOP terhadap Kosmetika, beliau menjawab bahwa BPOM memilikinya terkait SOP terdapat pada Peraturan Kepala BPOM NO.HK.03.1.23.12.11. 10052 Tahun 2011 Tentang Pengawasan Produksi dan Peredaran Kosmetika. Dalam paasal 2 tertulis setiap kosmetik yang beredar telah wajib:

1) Memenuhi standar mutu dan / atau persyaratan keamanan, manfaat, mutu, penandaan, klaim; dan

2) Dinotifikasi.

Dalam Pasal 3 tertulis pengawasan diilakukan melaluinya pemeriksaan terhadap:

1) Sarana; dan

2) Kosmetika

Pertanyaan serupa yang penulis ajukan adalah bagaimana mekanisme pengawasan produk kosmetik di pasaran, beliau menjawab pengawasannya diilakukan oleh industri kosmetika, importir kosmetika, usaha perorangan/

${ }^{22)}$ Peneliti (I), Op.Cit.

${ }^{23}$ Peneliti, Wawancara, dengan Riski Kurniawan S.H M.H, Kepala Sub Bagian Advokasi Hukum III, 29 November 2019, Jam 10.30 WIB. 
Volume 2 Nomor 2, Desember 2019

E-ISSN : 2655-7347

badan usaha oleh yang melakukan masa kontrak produksi dengan industri kosmetika yang lain yang telah memiliki izin untuk produksi, sarana diistribusi, dan sarana penjualannha melalui media e-lektronik.

Pelaksanaan nya tersebut pengawasan yang dilakukannya oleh petugas meliputi kepada pengawasan rutin dan khusus.

1. Pengawasannya oleh sarana dilakukan melalui:
a. Industri kosmetika
b. Importir Kosmetika
c. Usaha yang perorangan / badan usaha yang melakukan kontrak terhadap produksi dengan industri kosmetik yag sudah memiliki izin produksi;

2. Distribusi, meliputi namun tidak akan terbatas pada oleh distributor saja, agen, klinik kecantikan, salon, spa, swalayan, apotek, toko obat, dan toko-toko kosmetik. Pengawasan penerapannya aspek CPKB:

a) Industri ini kosmetik dengan telah izin produksi nya golongan $\mathrm{A}$ tersebut, harus menerapkan nya seluruh aspek CPKB;

b) Industri kosmetika oleh izin nya produksi golongan B, sekurangkurangnya telah menerapkan aspek higiene, sanitasi dan dokumentasi.

3. Pengawasannya kosmetik tersebut:

a) Pemeriksaan legal kosmetik

b) Pemenuhan oleh dengan persyaratan penandan, komposiisi, klaim, kesesuian antara komposisi dengan oleh klaim yang tercantum dalam penandaan kosmetika;

c) Pemeriksaan oleh dokumen;

d) Sampling dan pengujian nya berdasarkan analisis risiko;

e) Pengawasan promosi dan peiklanan kosmetika pada oleh media antara lain yang meliputi media cetak tersebut, media elektronik dan media luar ruang; dan 
Volume 2 Nomor 2, Desember 2019

E-ISSN : 2655-7347

f) Pemantauan hasil penarikan dan pemusnahan kosmetik yang tidak memenuhi nya persyaratan.

Dengan begitu terdapat koordinasi pengawasan peredaran kosmetika dengan lembaga lain seperti Menteri Perlindungan dan Menteri Perdagangan dan BPOM banyak bekerjasama dengan instansi-instansi di luar BPOM untuk pengawasan. Untuk diketahui saat ini organisasi BPOM didalamnya terdapat polisi, jaksa, tni dan bin untuk menunjang pengawasan. Adapun saran yang diberikan beliau bagi pelaku usaha sehubungan dengan peredaran kosmetika yang mengandung bahan berbahaya adalah kejahatan terjadi karena pelaku usaha biasanya ingin memperoleh keuntungan yang besar, contohnya banyak di asemka dan toko-toko lain di Jakarta. Meskipun sudah di jaring tapi tetap saja masih ada dan jika ada langsung di beri tindakan. Sebenarnya pelaku usaha paham akan kosmetika yang tidak ada izin redar dan mengandung bahan berbahaya tersebut tidak boleh dijual. Tetapi karna banyak nya permintaan konsumen maka pelaku usaha tidak terlalu memperdulikan nya, maka dari itu perlu kesadaran pelaku usaha itu sendiri untuk selalu mengecek dan mendaftarkan produk nya tersebut ke BPOM.

\section{Oktovia, Konsumen ${ }^{24}$}

Pada wawancara ini, penulis mengajukan beberapa pertanyaan kepada saudari Oktovia selaku pengguna atau konsumen kosmetika jenis cream, penulis ingin menanyakan jenis cream apakah yang digunakan, dan beliau mengatakan jenis cream yang beliau gunakan adalah La Widya Collagen Day Cream dan Korean Widya Night Cream. Dan sudah berapa lama beliau menggunakan cream tersebut, beliau mengatakan baru menggu nakan cream tersebut 3-4 mingguan terakhir dari bulan Juni 2019.

Pertanyaan serupa yang penulis ajukan adalah apakah alasan beliau memilih produk tersebut, beliau menjawab alasan nya memilih poduk

\footnotetext{
${ }^{24}$ Peneliti, Wawancara, dengan Oktovia, Konsumen, 15 November 2019, Jam 18.30 WIB.
} 
Volume 2 Nomor 2, Desember 2019

E-ISSN : 2655-7347

tersebut dikarena kan temen beliau juga memakai dan hasilnya bagus untuk kulit temen beliau, maka dari itu memutuskan untuk mencoba dan membeli nya. Dan bagaimana perubahan yang beliau rasakan pertama kali memakai produk tersebut, beliau mengatakan dalam kurun waktu 4-5 hari beliau merasakan perubahan dalam wajah nya, lalu merasakan pengelupasan terhadap kulit wajah nya, dan agak sedikit kemerahan, setelah hari berikut nya kemerahan tersebut merubah menjadi bercak-bercak hitam dan sedikit perih, dan menjadi flek hitam pada area dagu nya.

Penulis juga ingin menanyakan tentang Apa yang beliau lakukan setelah mengalami hal tersebut, beliau mengatakan segera menghentikan pemakaian cream tersebut dan mencoba menanyakan ke teman beliau apakah merasakan hal yang sama atau tidak, dan segera beliau ke dokter kulit untuk mencoba berkonsultasi mengenai kulit wajah nya, dokter tersebut memberi kan obat anti iritasi kepada beliau untuk menghilangkan rasa perih yang di alami di wajah nya. Dan Apakah teman beliau mengalami hal serupa seperti yang dialami nya, beliau mengatakan setelah beliau menanyakan ke teman nya, ternyata teman nya tidak mengalami apa yang di alami alami tersebut, justru kulit temen beliau baik-baik saja dan kelihatan bersih setelah pemakaian cream tersebut, beliau mengkhawatirkan apakah produk yang di pakai nya memiliki kandungan lebih keras atau bahan-bahan berbahaya lainnya, sehingga tidak cocok di kulit beliau.

Di sisi lain, penulis juga ingin mengajukan pertanyaan, apakah beliau meminta pertanggung jawaban terhadap pelaku usaha tersebut, dan dalam bentuk pertanggung jawaban seperti apa yang beliau inginkan, beliau mengatakan ya, bahwa beliau meminta pertanggung jawaban kepada pelaku usaha tersebut untuk memberikan penjelasan terhadap beliau dan meminta untuk membiayai semua perawatan yang akan beliau keluarkan (internal) dan kerugian (external) yang di alami nya yang mengakibatkan tidak bisa melakukan pekerjaan yang akan di ambil nya yaitu sebagai foto model di salah satu produk kecantikan. Setelah berunding 2-3 hari pelaku usaha tidak mau untuk bertanggung jawab atas apa yang terjadi terhadap beliau di 
Volume 2 Nomor 2, Desember 2019

E-ISSN : 2655-7347

karenakan pelaku usaha beralasan bahwa kejadian tersebut hanya terjadi kepada saudari Oktovia saja. Selama pelaku usaha tersebut berjualan belum pernah ada yang mengalami kejadian serupa dengan yang di alami beliau, maka dari itu beliau memutuskan untuk mengobati lukanya dengan biaya sendiri, dan tidak pernah mau membeli produk-produk kosmetik yang tidak terjamin lagi, dan hanya mengikuti arahan dokter kecantikan beliau.

3. Mulianto, Penjual Kosmetik ${ }^{25}$

Pada wawancara ini, penulis ingin mengajukan pertanyaan kepada Mulianto selaku penjual kosmetika reseller online, Jakarta. Penulis ingin menanyakan perihal dimana beliau menjual produk-produk kosmetika yang telah beredar luas tersebut, beliau menjawab selain membuka toko di daerah Mall Season City beliau juga menjual nya di beberapa toko online seperti Shope, Tokopedia, dsb, beliau sudah berjualan sekitar kurang lebih 1 Tahun dari 2018 lalu, selama berjualan beliau menerangkan bahwa belum ada yang mengeluh mengenai efek samping dari pemakaian kosmetika tersebut, dan beliau pun sebagai reseller percaya bahwa produk yang beliau jual tersebut aman dan tidak mengandung bahan berbahaya.

Pertanyaan serupa yang penulis ajukan adalah tentang apakah selama ini tidak ada tindakan pemerintah (dalam hal ini BPOM) untuk mengantisipasi peredaran dan pengawasannya, atau istilahnya melakukan sidak atau operasi. Beliau mengatakan bahwa kadang-kadang ada tetapi itu jarang sekali, dan biasanya pun ada orang atau pihak yang memberitahu sebelumnya jika akan adanya operasi atau razia tersebut, sehingga beliau bisa mengantisipasi untuk tidak berjualan di hari tersebut. Tetapi beliau tidak merasa resah dikarenakan beliau yakin bahwa produk yang dijual nya tidak mengandung zat-zat yang berbahaya.

Penulis juga ingin menanyakan perihal apakah selama ini ada yang menuntut ganti rugi atas sebab pemakaian produk-produk yang dijual nya, jika ada apa yang biasa dilakukan oleh beliau, dan beliau pun menuturkan

25 Peneliti, Wawancara, dengan Mulianto, Penjual Kosmetik di Mall Season City dan Reseller Online, 18 November 2019, Jam 14.00 WIB. 
Volume 2 Nomor 2, Desember 2019

E-ISSN : 2655-7347

bahwa ada satu atau dua orang konsumen yang memang menanyakan perihal yang terjadi kepada wajah nya atau efek-efek samping lainya, dan beliau menerangkan bahwa kejadian-kejadian tersebut biasa nya kesalahan dari konsumen itu sendiri, para konsumen biasa nya tidak mematuhi aturan pakai yang sudah tertera dan ada pula yang memang tidak cocok terhadap kandungan kosmetik yang ada didalam campuran kosmetik tersebut, maka dari itu beliau tidak mau atau menolak untuk bertanggung jawab atas perbuatan yang dilakukan oleh konsumen yang tidak mematuhi aturan pakai dan tidak ternyata tidak cocok dengan kulit nya, walaupun produk yang di pakainya adalah produk yang dibeli dari toko kosmetik miliknya, karna ada juga beberapa konsumen yang merasa puas dengan hasil dari produk yang dijualnya.

Dengan demikian, berdasarkan pendapat beliau jelas ada hal yang perlu digarisbawahi terkait dengan aspek peredaran kosmetik. Mengingat selama ini peredaran kosmetik yang mengandung bahan berbahaya sangat mudah beredar di pasaran tanpa adanya kontrol atau kendali dari pihak pemerintah, untuk itu aspek pengawasan dan penindakan oleh pihak berwajib mutlak diperlukan.

\section{PENUTUP}

\section{A. Kesimpulan}

Berdasarkan hasil penelitian yang telah dilakukan oleh Penulis, maka Penulis menarik kesimpulan sebagai berikut:

Berdasarkan Pasal 19 Undang- Undang Nomor 8 Tahun 1999 tentang Perlindungan Konsumen, toko obat atau kosmetika bertanggung jawab memberikan ganti rugi atau kompensasi atas kerugian konsumen pengguna kosmetik yang diperjual-belikan oleh pelaku usaha. Namun faktanya dilapangan, toko obat dan kosmetik yang penulis tuangkan dalam skripsi masih menjual kosmetik yang mengandung bahan berbahaya dan tidak memenuhi standart mutu tersebut, namun mereka tidak melakukan tanggung jawab sebagaimana semestinya dikarenakan toko obat dan 
Volume 2 Nomor 2, Desember 2019

E-ISSN : 2655-7347

kosmetik mengabaikan keamanan produk yang mereka perdagangkan padahal pihak BPOM telah melakukan sosialisasi untuk tidak menjual produk kosmetik yang tidak memiliki izin edar BPOM RI.

\section{B. Saran}

Bagi pelaku usaha sebaiknya mengetahui dan mempelajari keamanan dari produk yang diperdagangkannya atau yang diperjualbelikan tersebut, jangan hanya sekedar memikirkan keuntungan. Pelaku usaha juga sebaiknya mengetahui serta mempelajari Undang-Undang Perlindungan Konsumen mengenai kewajiban dan tanggung jawab toko obat dan kosmetik sebagai pelaku usaha karena sejatinya pelaku usaha memiliki peranan penting dalam perikatan jual beli antara toko obat dan konsumen.

\section{DAFTAR PUSTAKA}

\section{A. Buku}

Institute, Max Planck, "Advertising Cosmetic Products", International Review of Intellectual Property and Competition Law, Thomson Reuter, No. 28 Januari 1999.

Kristiyanti, Celina Tri Siwi, Hukum Perlindungan Konsumen, Sinar Grafika, Jakarta: 2014.

Nugroho, Susanti Adi, Proses Penyelesaian Sengketa Konsumen Ditinjau dari Hukum Acara Serta Kendala Implementasinya, Kencana, Jakarta: 2011.

Rajagukguk, Erman. dkk, Hukum Perlindungan Konsumen, Mandar Maju, Bandung: 2000.

Sutedi, Adrian. Tanggung Jawab Produk dalam Hukum Perlindungan Konsumen, Ghalia Indonesia, Bogor, 2008.

Yani, Ahmad dan Gunawan Widjaja, Hukum Tentang Perlindungan Konsumen, Gramedia, Jakarta: 2003. 
Volume 2 Nomor 2, Desember 2019

E-ISSN : 2655-7347

\section{B. Peraturan Perundang-Undangan}

Indonesia. Peraturan Kepala Badan Pengawas Obat dan Makanan

Republik Indonesia Nomor 19 Tahun 2015 tentang Persyaratan Teknis Kosmetika.

\section{Wawancara}

Peneliti, Wawancara, dengan Riski Kurniawan S.H M.H, Kepala Sub

Bagian Advokasi Hukum III, 29 November 2019.

, Wawancara, dengan Oktovia, Konsumen, 15 November 2019.

, Wawancara, dengan Mulianto, Penjual Kosmetik di Mall Season

City dan Reseller Online, 18 November 2019. 